\title{
Geological Context and Statistical Assessment of the Impacts of Sugarloaf Twin Disasters, in Western Sierra Leone
}

\author{
Yusuf A. Lahai' ${ }^{1}$ Prince S. Lahai Jr. ${ }^{2}$ \\ ${ }^{1}$ Department of Geology, Faculty of Pure and Applied Sciences, Fourah Bay College, University of Sierra Leone, Freetown, Sierra Leone \\ ${ }^{2}$ Department of Library, Fourah Bay College, University of Sierra Leone, Freetown, Sierra Leone \\ Email: lahaialhajiyusuf@yahoo.com,princesaolahai@gmail.com
}

How to cite this paper: Lahai, Y. A., \& Lahai Jr., P. S. (2019). Geological Context and Statistical Assessment of the Impacts of Sugarloaf Twin Disasters, in Western Sierra Leone. Journal of Geoscience and Environment Protection, 7, 226-247. https://doi.org/10.4236/gep.2019.76017

Received: April 11, 2019

Accepted: June 27, 2019

Published: June 30, 2019

Copyright $\odot 2019$ by author(s) and Scientific Research Publishing Inc. This work is licensed under the Creative Commons Attribution International License (CC BY 4.0).

http://creativecommons.org/licenses/by/4.0/

\begin{abstract}
In the event of natural disasters, Sierra Leone like any other country loses lives as well as properties and natural resources. Despite notable occurrences of small disasters in the country, only on August $14^{\text {th }}$ sugarloaf landslide and the resulting flash flood (twin disasters) which affected Regent and other communities in 2017 have captured both national and international attention due to their alarming impacts. To obtain a better knowledge on the nature of the disasters, this research considered the geological context of the landslide and focused on statistical analysis of the impacts of the twin disasters using Statistical Package for Social Sciences (SPSS). Geological field-based approach and self-administered questionnaires of both closed and open-ended questions, personal interviews and observations were adopted as research techniques. Descriptive statistics and qualitative analysis were used to analyze the data of the research. Relevant literature from books, journals, and newspapers was also consulted, including Radio, Television discussions and the internet. Slope destabilization that caused the Landslide was linked to the geology of sub-surface formation (highly weathered olivine gabbro), lineaments and the rate of weathering. Study showed remarkable economic, social and political impacts as a consequence of the twin disasters. Study also revealed that families assisted the most in both financial and non-financial ways to the victims, and renowned misappropriation of donated disaster funds. All variables tested using student $\mathrm{t}$-distribution and chi-square test of independence accepted the hypothesis. Information obtained from this work could be fundamental for policy makers and development practitioners (Osuteye \& Leck, 2017).
\end{abstract}

\section{Keywords}

Geological Context, Natural Disaster, SPSS, Slope Destabilization, Statistical Analysis 


\section{Introduction}

Landslides are ascertained as serious natural hazard common to mountainous or steep land areas across the continents; including Europe, Asia, South/North America and Africa. Its downward and outward movements are principally driven by gravity, which affects only a limited portion of the hill slope, with clearly defined boundaries at top, bottom, sides and the base (BGS, 2018). Their occurrence takes different formats, including slope failures, mudflows, and mass movements, which end up modifying the landscape and consequently cause severe damages and losses. Due to the huge fatalities and enormous damages attributed to landslide, particularly in topographically hilly zones globally, it is ranked as the third most dangerous disaster (Feizizadeh \& Blaschke, 2011). This establishes the relevance for identifying the natural (geological) conditions controlling and triggering landslides and also statistically showing its associated impacts, which inform rational decision in line with landslide risk management.

Landslides represent a serious geologic hazard (USGS, 2015) that results in loss of lives and property damages (Ramakrishnan et al., 2002). Globally, the figures for both damages and losses have risen considerably in the last decade, amounting to 32,322 recorded fatalities (Nsengiyumva et al., 2018). According to the United Nations' analysis, of the 346 recorded disaster incidents in 2015, a total of 22,773 people lost their lives. Analysis also shows that people affected from the same disasters reached a total of 98.6 million with an economic loss of USD 66.5 billion. It is surprising to note that landslide alone in the midst of other disasters affected 150,332 people with a death record of 4369 worldwide (p. 2). The world's poorest and wettest regions i.e. villages and cities across west and central Africa, face a worsening threat from the disaster according to researchers. Igwe (2017) reported that similar landslide incidences have claimed the lives of 4000 people over the past 10 years, and the loss of multi-million dollar resources each year in Africa (McAllister, 2017). These have posed serious constraints on the economic development of these developing countries, where the economic loss due to its impacts often distinguishes between economic growth and stagnation (Westen, 2000).

Freetown, the capital city of a small West Africa country, Sierra Leone, has been struck by different types of mass movements/landslides and associated flash flood (see historic and recent slides in Figure 1(a)). Its vulnerability to the disasters is also validated by historical analysis available from the International Disasters Database (EM-DAT) and Freetown City Council (2014) combined hazard analysis report in the country, conducted in 2014. From 1990 to 2004, landslides accounted for $42.7 \%$ of the reported geophysical/geo-hazard mortalities, exceeding floods, storm and fire. $86.3 \%$ of the country's economic losses during the same period were also caused by the combined hydro-meteorological disasters (UNDP \& EPA, 2017).

The topographic nature of Freetown; containing numerous hills and mountains, coupled with intense precipitation experienced during August and Sep- 
tember, has made it susceptible to landslides and flooding. City planning has been given little priority in the EU-funded Freetown Development Plan created in 2014. As a result, homes/houses have been constructed in areas identified as "at risk". Also, protected forest areas on the hills behind the city including other prohibited areas have all been encroached contributing to most slope failures (Egbejule, 2017). Despite the fact that the Freetown Layered Complex has significant natural ground instability due to landsliding, little or no related scientific research has been done, offering the peninsula as an excellent site for landslide causative factors and impact studies.

The research will therefore bridge gaps and improve landslide knowledge for future initiatives related to landslide risk reduction and management in this part of the country. Furthermore, the outcome of the impact study will bring potential economic, social, political and by extension environmental effects to the knowledge of policy makers and development practitioners.

The National Disaster Management Department (DMD) in the Office of National Security (ONS) is the only mandatory sector according to the National Security and Central Intelligence Act in 2002 that coordinates disaster management at various levels and aids in promoting cross-sectoral disaster management activities (Sierra Leone Disaster Management Policy, 2006). However, the department has not been capable to manage disasters since its inception in 2004 due to lack of financial and material resources. Additionally, there has been a non existence of comprehensive Disaster Management Strategy (DMS), uncoordinated responsibilities, untimely response to disasters by both national and government as a result of their poor capacity, and improper integration of civil societies into effective disaster management prior the August $14^{\text {th }} 2017$ disaster.

The most recent twin disasters in Freetown have confirmed the ineffectiveness of the Country's Disaster Management Department in managing disasters. They recorded the worst ever in history and can be compared to the past natural disaster that occurred at charlotte in 1945 and September 2015 respectively; and also showed how vulnerable the population are to the risk of landslides and associated flash floods. The death rate and property destruction of the two events during those periods were not quite alarming as of on the $14^{\text {th }}$ August, 2017 rainfall triggered disasters that left Regent and four other communities also mentioned by United Nations Office for the Coordination of Humanitarian Affairs (UN/OCHA 2017), seriously affected. It is estimated that 493 corpses were found and about 600 corpses were missing or buried in the debris of avalanched recent mudslides and over 6000 people affected overall (McCarthy, 2017). Apparently, these two natural disasters have caused the death of about 14,400 and over 600 more missing since 2013-2017 torrential rainfall in Sierra Leone (Gibbins, 2017). The population density of Freetown estimated as 1224 people/square kilometers prior to the disasters has been drastically reduced, with concomitant effects on the labour supply (800 work force in Freetown) that are supposed to work for the development of the country. Apart from the loss of 
lives, houses, mosques, churches, schools, recreational and entertainment centers, agriculture, safe drinking water sources and commercial activities (petty trading, shops) have all been devastated (Kamara, 2017b). Furthermore, water supply, fishery products, sewage disposal systems, forests, dams and roadways were greatly affected and eventually reduced the little Gross Domestic Product (GDP) of less than 7.5\% (Ministry of Information \& Communication, 2016).

Based on the damage and loss assessment done by World Bank, it was estimated that a total economic value of the effects of the twin disasters summed up to USD 31.65 million. A total recovery need was estimated at USD 82.41 million, with USD 40.54 million needed for recovery interventions in the first year, and USD 41.86 million for the second and third year respectively (Sierra Leone MoFED, 2018). However, the natural disasters affected every citizen, be it victim or non-victim either directly or indirectly (Free Encyclopedia, 2017). But the victims were the hardest hit of the disasters than the non-victims. The effect of the twin disasters on both victims and non-victims cannot be over emphasized. Mitchell (2017) also asserted that the negative economic effects of the recent disasters include the cost of repairing structures, and recovering of properties which include 349 buildings, and transportation routes (p. 21). Medical cost, and indirect costs such as lost timber and lost fish stocks, water availability; both quantity and quality are currently affected by these natural disasters.

Corruption reports from victims, families and Auditor General's office on the handling of funds and materials donated were common during post-disaster period, justifying the Transparency International's report that ranked Sierra Leone as the 150 of 179 countries third highest, with corrupt practices (Economic-Freedom Index, 2009). Political processes were also disrupted as a consequence of the disasters. According to National Electoral Commission (NEC, 2017) Sierra Leone, the election processes are always affected in the event of any natural disaster since eligible voters, polling agents and officers die as it happened during the twin disasters. Efforts therefore should focus on extensive geological investigations to establish how natural (geological) factor influenced the Sugarloaf rain triggered landslide and to document the impacts of the twin disasters both qualitatively and quantitatively.

In addition to the above, United Nation Development Programme (UNDP) in collaboration with Environment Protection Agency (EPA) in 2017 undertook a work on the "Analysis of Causal and Trigger Factors" of the August 2017 Landslide in Freetown, which was geared towards a sustainable landslide risk management in the country. The report was hugely based on documentary analysis/desktop investigation/secondary data sources with only two field visits that focused on the holding centers and few affected communities in the eastern end of Regent. There has been no extensive field based geological work and comprehensive statistical study of the twin disasters. This work therefore seeks to unravel the following; a) the level of geological influences on sugarloaf's landslide (b) the impacts of landslide and associated flash flood on the affected communi- 
ties using Statistical Package for Social Sciences (SPSS) version 16. This necessitates a better understanding of the nature and scale of urban risk to the disaster.

The results of field investigations were crucial to identify geological conditions controlling and triggering the landslide. The flash flood resulted from an intense rain that fell on Sierra Leone from $1^{\text {st }}$ July-14 $4^{\text {th }}$ August 2017 . The World Bank (2017) estimated $1040 \mathrm{~mm}$ of rain during this period, exceeding three times more than the average. Affected communities considered in the research, including Matormeh, Kaningo, Pentagon, Lumley, Kroobay and culvert, show negative economic effects. Ameliorating this requires huge cost of expenditure in rebuilding new communities for the victims and the provision of medical facilities for the injured (Amnesty International, 2017). Also, entertainment and political process were disrupted as a result of the disasters.

\section{Material and Methods}

\subsection{Study Area Profile}

Sugarloaf landslide occurs at Matormeh, which is located in the outskirt of Freetown that overlooks regent mainland and the Congo Reservoir, and is also strategically located southward in a protected area of the National park. It falls within zone-3 of the topographic map of Freetown layered complex and also found on sheet-2 of the western area of Sierra Leone (Chalokwu, 2001). The
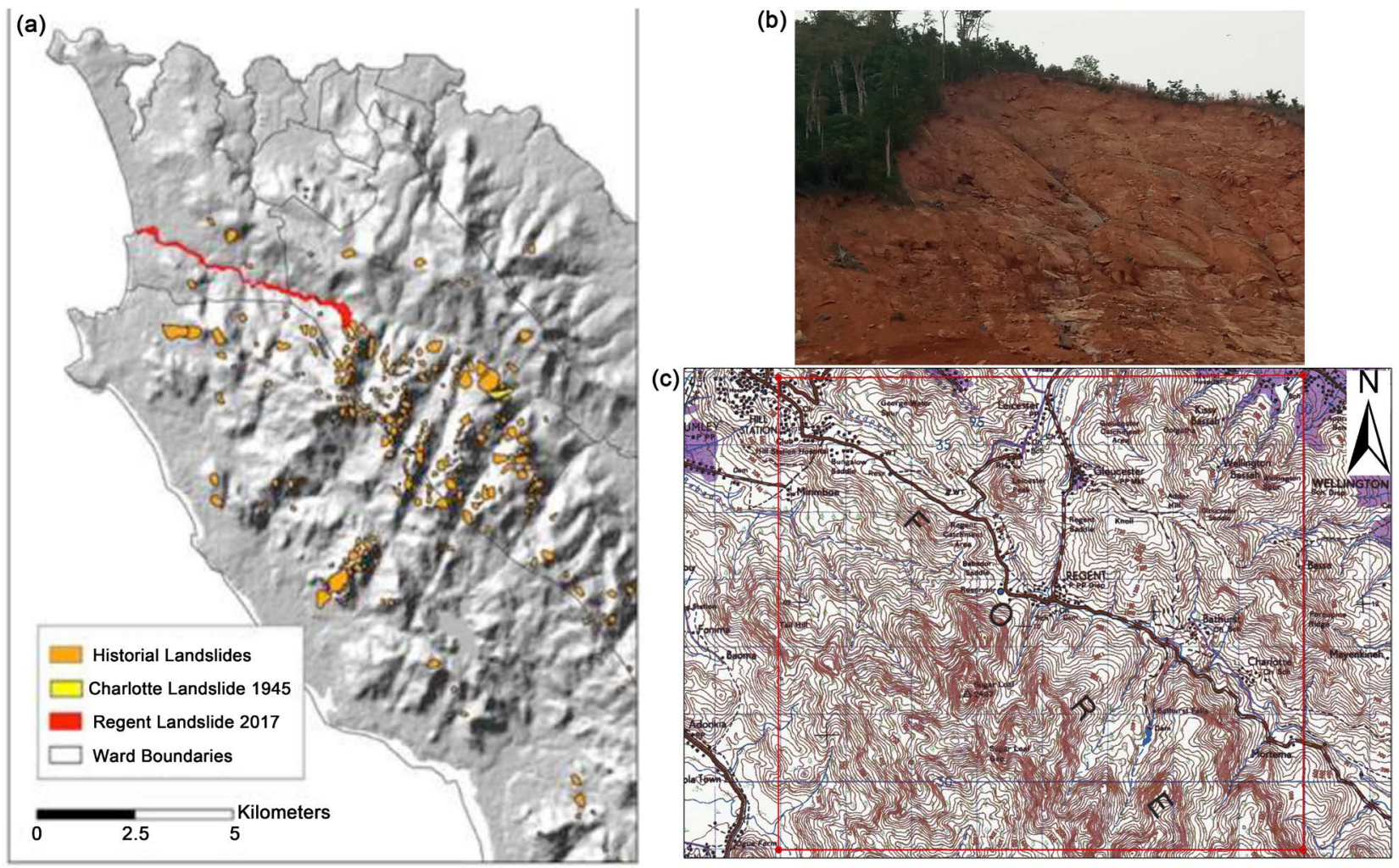

Figure 1. Location of study area; (a) $14^{\text {th }}$ August 2017 landslide in relation to historic slides (Source: World Bank 2017); (b) Landslide area at Sugarloaf Mountain (Source: Authors' field photo, 2018); (c) Contour map of study area and surrounding (geomorphology) and drainage system represented with blue lines (Source: National Minerals Agency 2019). 
landslide dimension is $600 \mathrm{~m}$ by $200 \mathrm{~m}$ and a rupture depth ranging from 5 to 10 $\mathrm{m}$ (BGS, 2017). The resulting flash flood triggered by heavy rainfall affected few communities. These communities (Kaningo, Pentagon, Lumley, Kroobay, and culvert), were considered in the statistical analysis. The total run-out was estimated $6 \mathrm{~km}$ down flooded channel to sea. See Figures 1(a)-(b).

The area is characterized by undulating mountain ranges with tight narrow valleys dissecting the surrounding hills. The landslide's epicentre is steep, and has a slope gradient of $>60^{\circ}$ (Sillah \& Williams, 2017). Geomorphologically, the landslide area is seemed denuded due to anthropogenic activities (forest logging and settlement). Additionally, there are observable scars or gully erosions around the main landslide body in Regent thought to be associated with lineaments (UNDP \& EPA, 2017).

Freetown often has a heavy down pour of rains in the months of August and September which is considered the height of the rainy season. According to BBC (2017), the height of the rainy season in Sierra Leone normally has an average of $539.9 \mathrm{~mm}$. This has always caused continuous flow of water and debris via the streets, and this time round, has accelerated a massive landslide with severe damages that emanated from it. The resulting flash flood triggered by the heavy rainfall pushed earth materials from Regent to Lumley. Figure 2 presents the average monthly rainfall from July 2016 to July 2017.

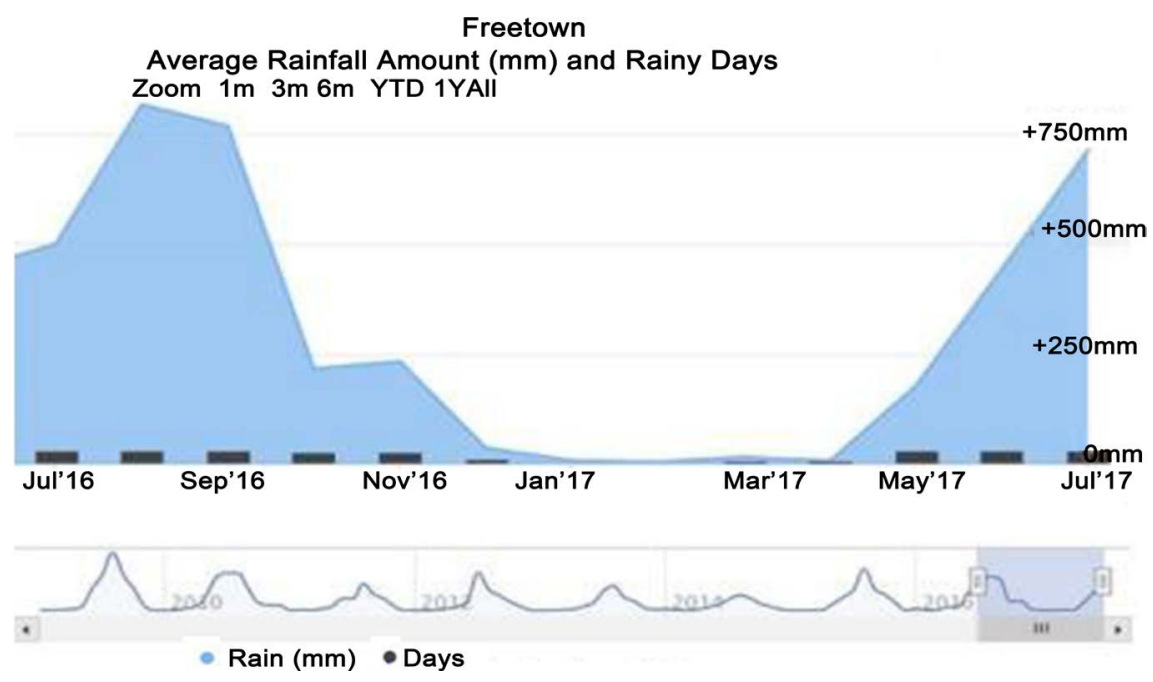

Figure 2. Average monthly rainfall in Freetown (July 2016-July 2017); about 33.3\% of the rains in August 2017 (Source: World Weather Online 2017).

\subsection{Field Work}

This includes the extensive non-consecutive fieldwork carried out for Thirteen (13) days (26 $6^{\text {st }}-28^{\text {th }}$ August, 7-9 $9^{\text {th }}$ September, 2017 and $7^{\text {th }}-13^{\text {th }}$ October, 2018) and the one day trip undertaken together with the British Geological Survey (BGS) and United Nation Organization for Population Studies (UNOPS).

The first three days of the former field trip (22-28 ${ }^{\text {th }}$ August, 2017), focused on the identification, measurement and recording of geological parameters, and sample collection where necessary. Parameters noted include; lithology, depth of 
weathering, fracture/fault/joint set orientation (which constitute lineaments of the landslide), diameter of boulders, thickness of bouldery debris, landslide dimension and slide volume.

The next three days $\left(7^{\text {th }}-9^{\text {th }}\right.$ September, 2017) concentrated on self-delivered questionnaires. The study population accounted for only the local residents of the affected communities. They include headmen/elders, teachers, students, traders, skilled workers and NEC registration officers. A stratified simple random sampling selection of victims at each community was adopted, with a sample size of sixty (60) victims of the twin disasters. The last seven $\left(7^{\text {th }}-13^{\text {th }}\right.$ October, 2018) days of the former trip was dedicated to monitoring of discontinuities (fracture width in this case), nearby potential sliding zones and other informal interviews.

The latter trip done together with UNOPS and BGS involved site visit for ground truthing, observation of landslide deposits on slopes and along stream channels, taking of drone images/photographs and informal interviews with locals on the impacts of the disasters.

\subsection{Statistical Method}

The second part of the research was based on the impacts of the twin disasters in the study area, Freetown. For this reason, both qualitative and quantitative methods were used as described by Salkind, 2006. The qualitative research methodology was used because the research involved the meticulous description of the impacts of the twin disasters on Freetown municipality. The quantitative research methodology on the other hand was equally used because the exercise involved a great deal of number work, as the raw data collected for the study were cautiously analyzed and presented in statistical form; using Statistical Package for Social Sciences (SPSS) version 16 to construct table, and extrapolate bar charts revealing the number and percentages of victims affected by the Landslide and flash flooding for each effect identified.

For test of hypothesis, various variables were tested using Student's t-Distribution Test and Chi-square Test at $5 \%$ significance difference. This was done by inputting codes/data values into the Software Packages for Social Science (SPSS) system ranging from $1-8$ and others $1-3$ respectively. This method is simple and it is widely used in journal publications.

The research tools employed were questionnaires, conversational interviews, and personal observations. More precisely, sixty (60) questionnaires were administered. To complement the questionnaire method, conversational interviews and personal observations were also utilized by the researchers.

\section{Results and Discussions}

\subsection{Geological Context}

The Sugarloaf landslide consists of variable slope gradients along the flanks. The Western flank is steeper than 60 degree towards the head scarp and a range between 20 and 30 degrees at the bench, where as the slope of the eastern flank is 
greater than 45 degree at the top and between 20 - 25 degrees towards bench. Despite the study area's geomorphology is indicative of natural ground instability, understanding the geological framework of the rainfall-triggered landslide is pivotal to link slope destabilization due to sliding to the underlying rocks and structural geological conditions.

\subsubsection{Geology}

Fractured and layered gabbroic rocks (olivine gabbro, gabbro and basaltic dykes) underlie the landslide area (See Figure 3(b)). The much visible major fracture set at the headscarp has a WNW-ESE trending. Two minor fracture sets constituting part of the lineaments on the same landslide headscarp are observed trending E-W and WNW-ESE directions with a northward and NW dips respectively, that are almost parallel to the slope. The weathered NNE joint/fault zone on the second slide surface has dip ranging from 45 - 50 degrees. The orientation of the lineaments described above controlled the sliding form, particularly in the upper part of the slope (i.e. some form landslide planar). Hydrologically, water spout from open fractures and fault/aper joints in rock mass. The flowing water followed the sliding planar, most likely caused by lineaments (fault/fracture). See Figure 3(a) and the corresponding cross section in Figure 4.
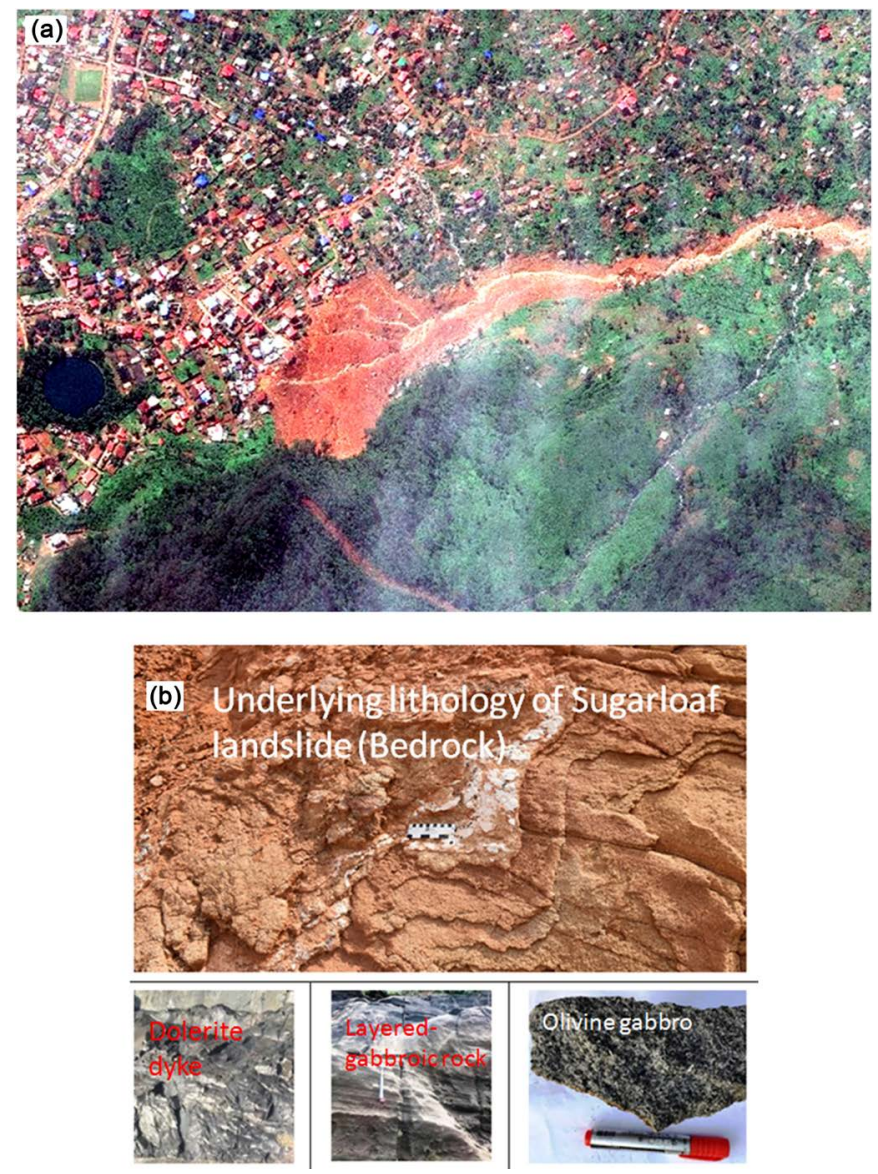

Figure 3. (a) Satellite image of landslide ( $15^{\text {th }}$ August, 2017) and corresponding schematic cross-section; (b) Bed rock geology of the landslide area (Authors' field photo 2018). 


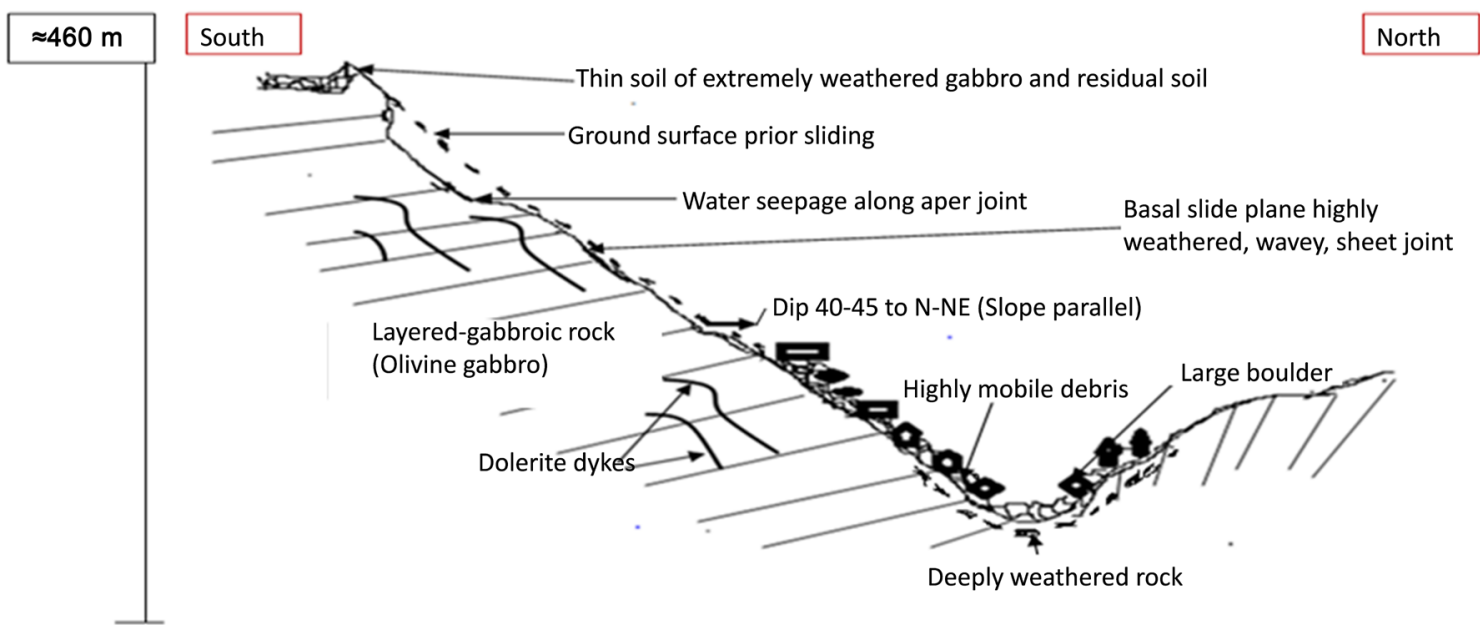

Figure 4. Broader view of schematic cross-section of sugarloaf landslide (See satellite image).

\subsubsection{Weathering}

Weathering of the fractured/jointed and bedded intrusive underlying gabbroic rocks is intense. More cracks were generated by water and possible lineaments, which eventually triggered rock friction. The observed weathering profile at the ridge top is relatively thick with a thin regolith $(1-5 \mathrm{~m})$ on the eastern flank towards the headscarp (See Figure 5 left). Numerous boulders partially submerged in the thick sediments seen on adjacent surfaces of the landslide area and weathering/soil profile, are indicative of differential weathering, and always constitute the earth materials that eventually move downslope during mass movement. An effective transport medium was facilitated by the heavily weathered surface soil and varies according to the accumulation of mass and particles. On the main rupture surface, there is an out stretch of a thick weak layered zone (completely weathered) estimated between 0.5 and $1 \mathrm{~m}$, and conspicuous clay along joint infill (white minerals) as seen in Figure 5 right. Weathering at the lower part has an estimated average thickness of about $55 \mathrm{~m}$.

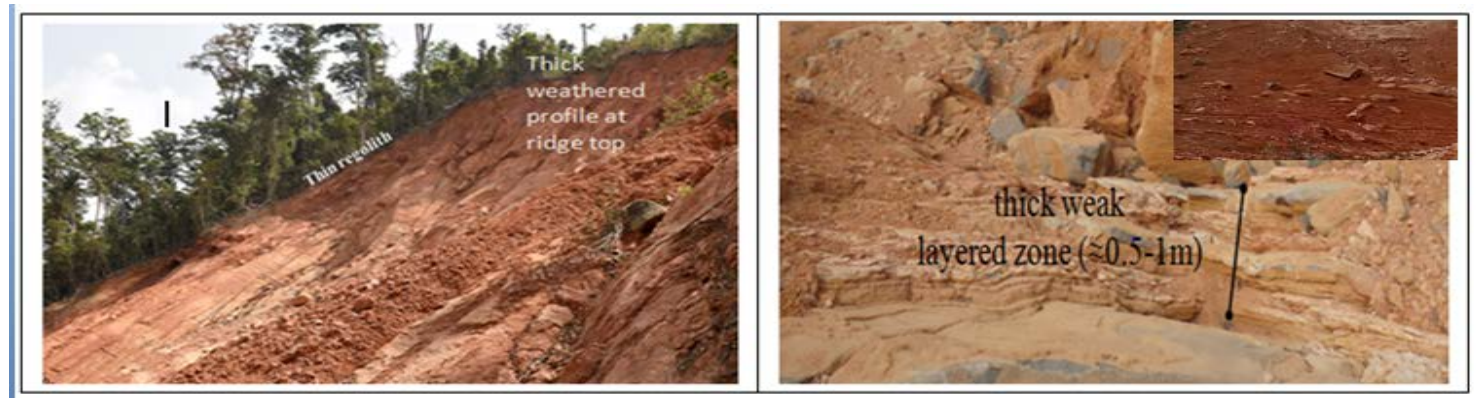

Figure 5. Thick weathered profile at ridge top, water generated cracks and thin regolith-Headscarp area (Left); an out stretch of a thick weak completely weathered zone at the rupture surface with clay present in the joints (Right) and weathered materials at slope base (Right's top corner). Source: Field photo by team (BGS and author 2018).

\subsubsection{Types of Materials and Movement}

The landslide generated different types of materials, proportionately distributed over the entire landslide area and along stream courses, including boulders (1.5 - 5 
$\mathrm{m})$, sand, silt and clay according to Wentworth scale classification. Even though boulders are clearly visible, some are submerged by medium to fine-grained sediments at the lower gradient, defined by planar slope. Some suspended within the debris mantel at the eastern flank and bench ( 1 - 3 bouldery debris on insitu bedrock), and others along gulley/springs. The headscarp and the mid slope showing exposed bed rock after mass movement is scarce in landslide generated materials.

Two kinds of movements dominated the landslide. The relatively thick residual soil comprising numerous boulders, and cobbles which overlaid the bedrock underwent rapid mass movement down slope when mixed with water (triggering factor) to form the debris slide. The embedded boulders were released and bounced along the steep slope, down to the lower slope and continued along the drainage channel. This describes boulder bounce. Mudslide was enhanced by the flash flood, and showed visible tracks. Compositionally, it constituted at least 50\% sand, silt and clay-sized particles, combined with 30\% water. Figure 6 illustrates the proportional distribution of landslide materials, mud tracks and material movements.

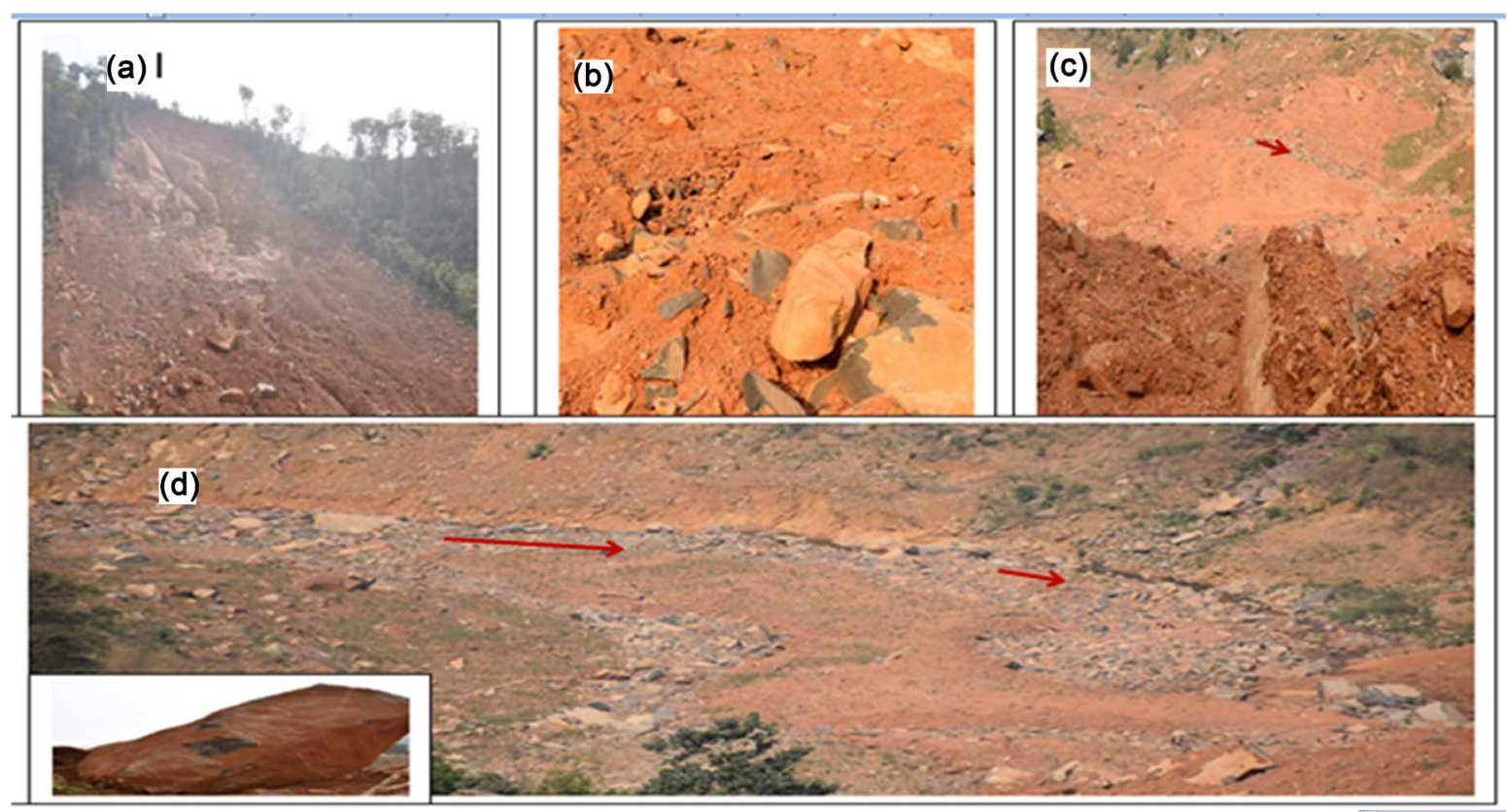

Figure 6. (a) Landslide area showing upper sliding plane and debris accumulations; (b) Debris and implied rock bounce); (c) Bedrocks in riverbed and thicker bouldery debris (5 - $9.5 \mathrm{~m}$ ); (d) Mudflow track at landslide base (source: Authors' field photo and BGS/UNOPS' team 2018).

\subsection{Effects of Landslide and Flash Flooding}

This part provides both qualitative and quantitative data derived from techniques indicated in the methodology. Data obtained from questionnaire are presented in the form of frequencies (number of victims), percentages, and bar charts. Responses were computed using Statistical Packages for Social Sciences (SPSS); followed by discussion from interview, observation, reports, books, journal articles and internet downloaded on the effects of the $14^{\text {th }}$ August, 2017 natural disaster in Freetown, Sierra Leone. 
From Table 1, the valid percent shows the actual percentage of each frequency while the cumulative percentage is the successive additions of each valid percent unto one hundred percentages as the cut-off point. On the other hand, the cumulative percent column determines us to prove whether or not the computation is complete hundred percent (100\%). Thus, it is evident that valid percent has a direct relationship with cumulative percent. However, only the valid percent is considered in this research in order to avoid duplication.

Table 1. Victims' Location (Source: Field data on $7^{\text {th }}-9^{\text {th }} / 9 / 2017$ and SPSS version 16.0 ).

\begin{tabular}{cccccc}
\hline & Victims' Location & Frequency & Percent & Valid Percent & Cumulative Percent \\
& Regent & 10 & 15.9 & 16.7 & 16.7 \\
& Matormeh & 8 & 12.7 & 13.3 & 30.0 \\
& Kaningo & 8 & 12.7 & 13.3 & 43.3 \\
\multirow{3}{*}{ Valid } & Pentagon & 9 & 14.3 & 15.0 & 58.3 \\
& Lumley & 10 & 15.9 & 16.7 & 75.0 \\
& Kroobay & 9 & 14.3 & 15.0 & 90.0 \\
& Culvert & 6 & 9.5 & 10.0 & 100.0 \\
\multirow{3}{*}{ Missing } & Total & 60 & 95.2 & 100.0 & \\
& System & 2 & 3.2 & & \\
\hline
\end{tabular}

The table shows that 16.7 valid percent of ten victims are from regent, $13.3 \%$ $(\mathrm{f}=8)$ victims are from Matormeh, $13.3 \%(\mathrm{f}=8)$ victims are from Kaningo, $15 \%$ $(f=9)$ victims are from Pentagon, $16.7 \%(f=10)$ victims are from Lumley, $15 \%$ $(f=9)$ victims are from Kroobay and $10 \%(f=6)$ victims are from Culvert community where the twin disaster occurred.

Invisibly, the table also portrays that $21 \%(\mathrm{f}=12)$ victims are between the age of $11-20 \mathrm{yrs}, 25(\mathrm{f}=15)$ are between the age $21-30 \mathrm{yrs}, 28.3 \%(f=17)$ victims are between the age of $31-40 \mathrm{yrs}, 18.3 \%(\mathrm{f}=11)$ victims are between the age 41 $50 \mathrm{yrs}$ and $8.3 \%(\mathrm{f}=5)$ victims are $61 \mathrm{yrs}$ and above.

\subsubsection{Economic Effect}

\section{1) Direct Economic effect}

From Figure 7 (left), 6.7\% ( $f=4)$ of the victims revealed that "Backyard Garden, Livestock, and Quality Water" were affected when the disasters struck. While $51.8 \%(\mathrm{f}=31)$ of the victims indicated that their "Houses and Petty Trading" were affected; $8.3 \%(\mathrm{f}=5)$ victims showed that their "Hairdressing, Shoemaking, Catering Service, Restaurant/Cookery Shop and Dressmaking" were adversely affected; $5 \%(f=3)$ victims indicated that there "Carpentry workshop" was destroyed; and $3.3 \%(f=2)$ weaving were also affected during the avalanche twin disasters.

From the chart the highest bar represents house and petty trading disrupted in those affected communities due to the disasters. As indicated by Mitchell (2017), 

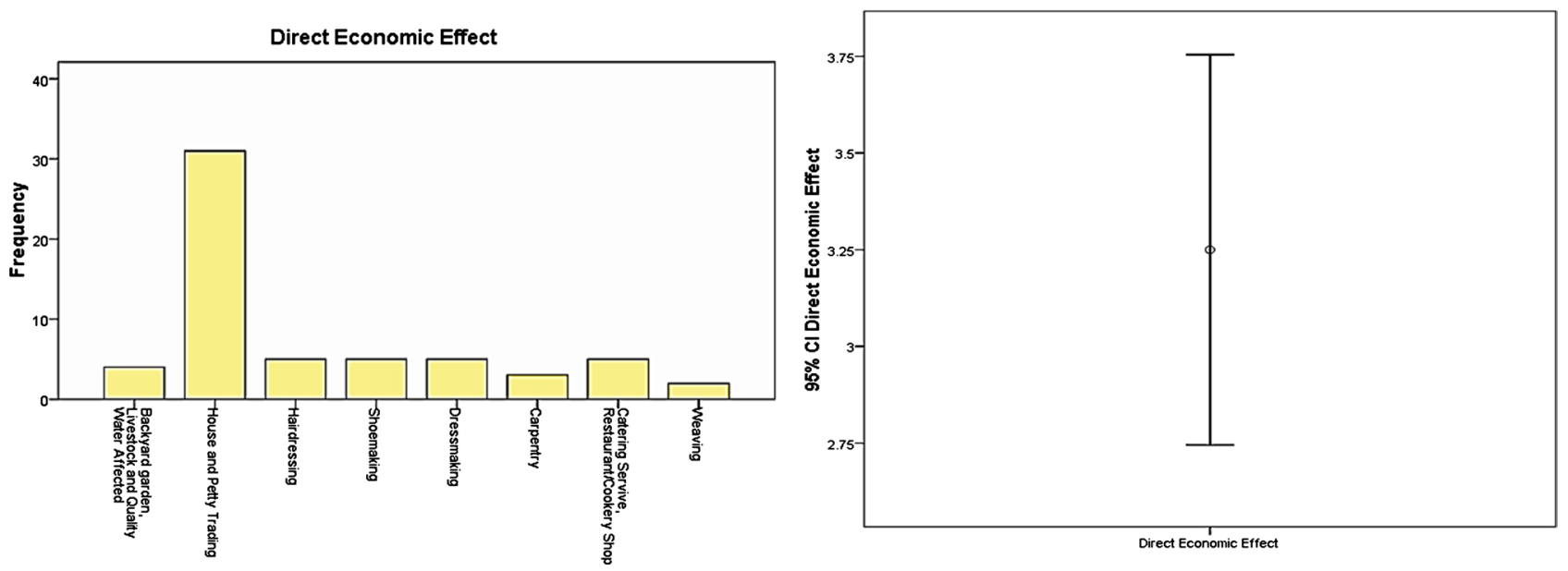

Figure 7. Direct Economic effects (Left) and Error bar (Right) (Source: Field data on $7^{\text {th }}-9^{\text {th }} / 09 / 2017$; SPSS version 16).

the negative economic effects of the recent twin disasters include the cost of repairing structures, and recovering of properties including 349 buildings and disrupted transportation routes. Medical cost, and indirect costs such as lost timber and lost fish stocks, water availability; both quantity and quality are currently affected by these disasters (p. 6). The flash flood might result in cholera outbreak and other diseases if not addressed. Again the direct effect on citizens was the destruction of houses, disruption of subsistence and cash crop farming activities, livestock among other things. Statistical result also indicated the drastic reduction of the Gross Domestic Product (GDP) from 2013-2016 as a result of persistent natural disasters which include flooding and recent mudslide events (Gibbins, 2017). The two sectors, mining and agriculture, on which the country depends on to generate its Gross National Income (GNI), were badly affected. For the agricultural sector, the forest that is made to produce timber, wild life conservation, the quality of water was affected. This portrays that, in terms of monetary value, the timber and wildlife were all lost instead of increasing the GDP of Sierra Leone. Some mining companies operating on certain minerals were halted because of the recent report that stated that the sector was one of the major causes of mudslides, which in turn will reduce the GNI. From the sample, stated that the indirect effect of the recent natural disasters was the increase in the general price in the market especially for food products. This in turn has affected the real income in which eighty-one point seven percent of forty-nine victims consented. This reduction of GDP can affect the per-capita income (monthly salary) of the individuals, be it victim or non-victim of the disaster. This is due to the persistent increase in the general price level of the country as a result of this major agricultural destruction. Sierra Leone being one of the poorest African countries in the world, could hardly feed itself sufficiently let al.one there is frequent occurrence of natural disasters. The reduction of GDP will always have a chain effect on the income of its citizens due to inflation. The World Bank report estimated that sixty (60\%) percent of Sierra Leoneans go without food every day, this means that the average Sierra Leonean lives below one dollar 
(\$1) a day (Dumbuya, 2018). Furthermore, not only has agricultural sector affected, but also the commercial sector (Small Scale Business Centres) such as petty trading, hairdressing, weaving, catering services, carpentry, dressmaking, barbing shops, shoemaking (Kamara, 2017a). These activities done in affected communities were disrupted/destroyed which was another setback for livelihood sustainability of families as indicated in the chart. These Small Scale Businesses (SSB) play a pivotal role in the social, socio-cultural and economic development of the country. They contribute positively to the living standard of people.

\section{2) Humanitarian Assistance}

Figure 8 (left) extrapolates that $8.3 \%(f=5)$ victims stated that they received assistance from "international and National Committee, and Countries"; while $25 \%(\mathrm{f}=15)$ victims indicated that they received assistance from individuals since the disasters struck; For sympathizers, $16.7 \%(\mathrm{f}=10)$ victims indicated they received assistance; Also, 33.4\% ( $\mathrm{f}=20$ ) victims stated that they received assistance from "Families", the highest bar. Some of the listed assistances are as follows: finance; bed, food, clothe, shelter and Kitchen utensils etc. Though of late, Government has constructed houses for some victims and there are still a good number of victims languishing without such assistance.

From the chart it reveals that, there are currently hundreds of people affected by the twin disasters who are not receiving food everyday despite huge relief donations and funds from national and international committees, countries, individuals, sympathizers, and families etc. to assist the Government of Sierra Leone (Roy-Macauley, 2017). Instead of using the minimal national income/consolidated funds of this country to feed and provide accommodation for the victims of the deadly disasters that struck on that day, those donations and funds were diverted (Kamara, 2017b). In the wake of natural disasters, people always seize the opportunity to survive, as there are now some people claiming to be victims/survivors of this disaster to make ends meet. This is because there has been vast majority of individuals suffering to get a daily meal to survive. Freetown
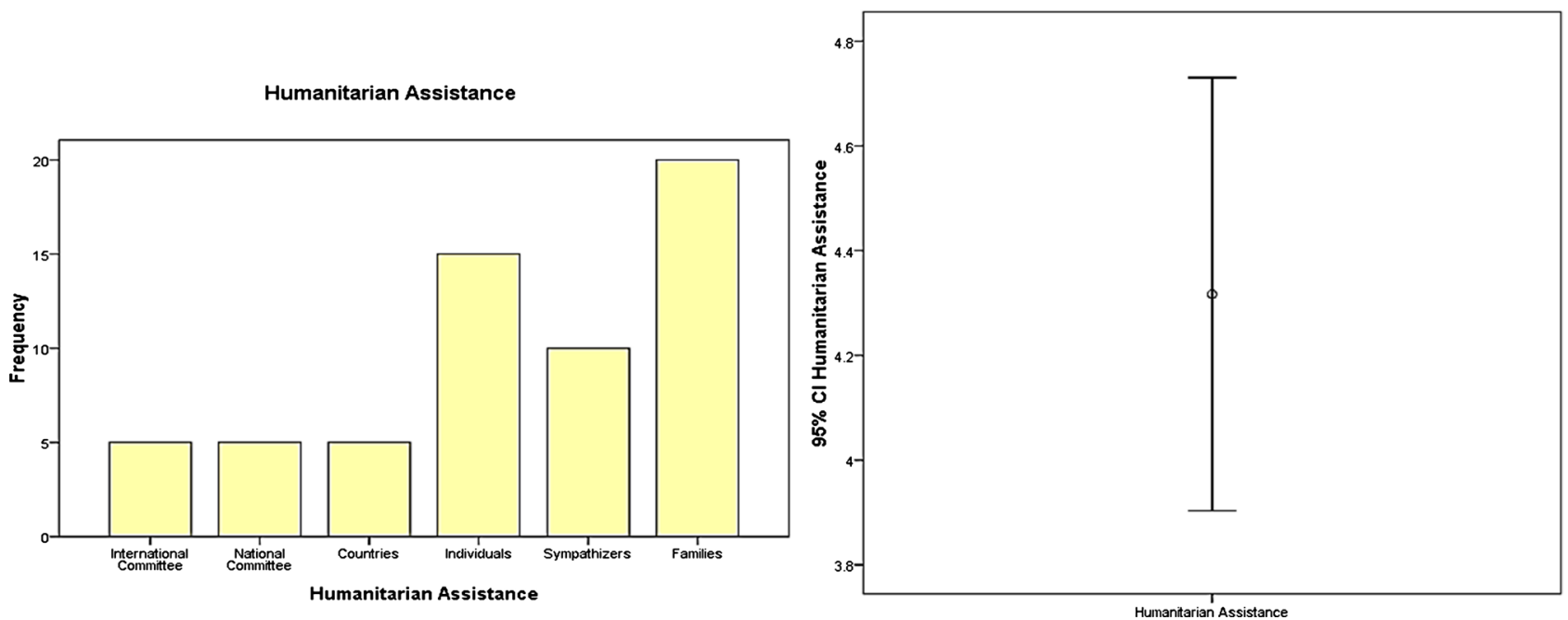

Figure 8. Humanitarian assistance (Left) and Error bar (Right) (Source: Field data on $7^{\text {th }}-9^{\text {th }} / 09 / 2017$ and SPSS version 16.0). 
being the most populated city in Sierra Leone where the twin disasters occurred with more than thousands lives gone has reduced the man-power/labour force. This labour force could have lived to contribute to the GDP for national development. It is indeed a big blow/setback to Sierra Leoneans and not only the victims/survivors of the deceased (Baraytay, 2017). The twin disasters record the worst ever in the history of Sierra Leone which has gone through many trials from the civil war to the 2014 EBOLA outbreak. The disasters occurred so fast within six hours (6 hrs.) and caused massive deaths of Sierra Leoneans. However, family members in Freetown and less disaster affected areas are presently providing great deal of support to people affected by these disasters as portrayed on the chart. Though some are receiving financial assistance as well as items like mattresses, kitchen utensils, food, clothing, shelter; etc. the bulk of this financial assistance came from siblings, children and family friends. But some are still claiming of not getting any financial assistance since the disasters struck.

\subsubsection{Social Effects}

\section{1) Education and Health}

From the chart described by Figure $9(\mathrm{left}), 16.7 \%(\mathrm{f}=10)$ victims indicated that "School Buildings" were destroyed in the twin disasters; $11.6 \%(f=7)$ victims indicated "Hospital" was destroyed; $15 \%(f=9)$ victims indicated "Pharmacy" was destroyed; $6.7 \%(f=4)$ victims indicated "Clinic" was affected; and $50 \%(\mathrm{f}=30)$ victims indicated "School building, Pharmacy, and Clinic" were destroyed when the disaster struck in the affected communities. On this note seventy-five percent of sixty victims agreed that children affected have stopped attending school as many school buildings were destroyed when the disasters struck. But this has reversed the process with the advent of new government flagship programme 2018 "Free Education for Primary and Secondary School".

As indicated from the chart; education, pharmacy and clinic have the highest percentage of destruction from the disasters. Education is the backbone of a
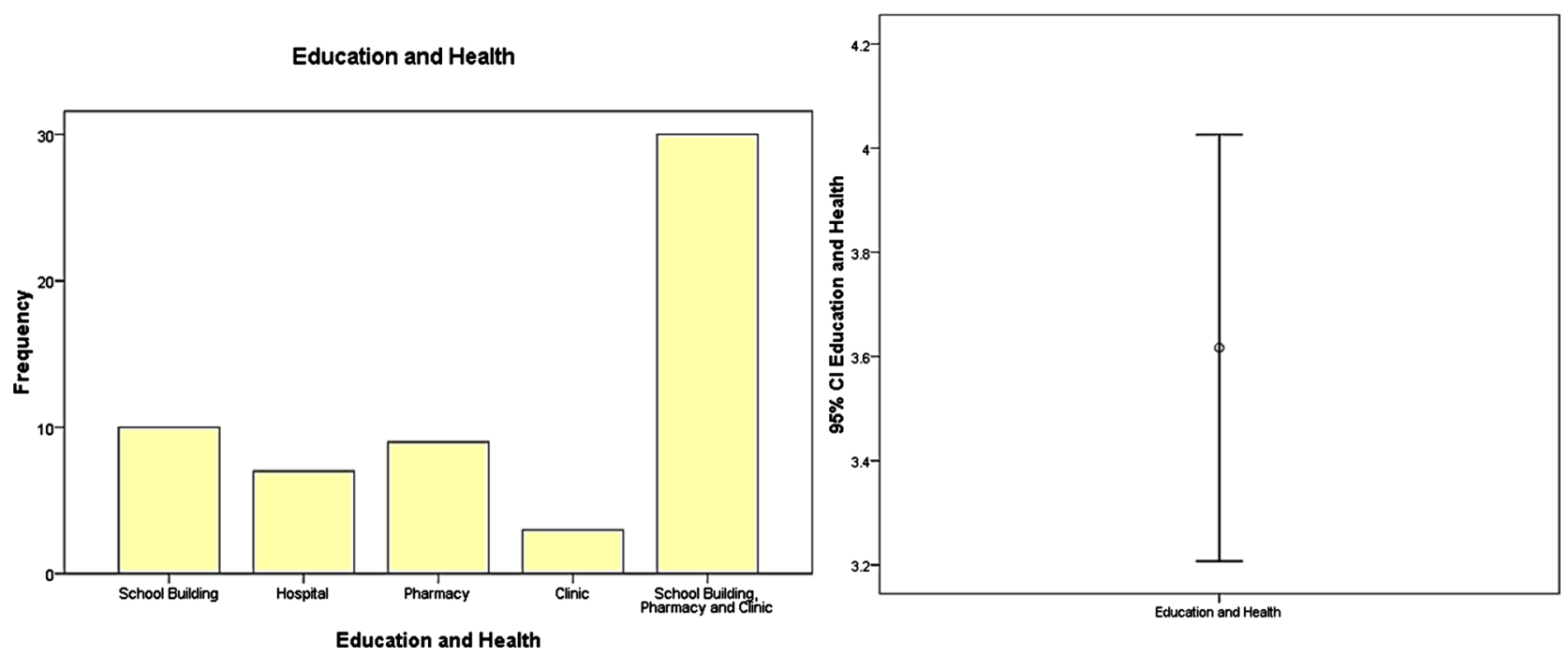

Figure 9. Education and health and error bar (Right) (Source: Field data on $7^{\text {th }}-9^{\text {th }} / 09 / 2017$ and SPSS version 16.0). 
country's development, so it is a priority for individuals' personal development (UNDP, 2015). In this light, the schooling of hundreds of children was affected as those victims' parents died or if alive, their properties were destroyed. As Mbalu Bangura (2017) lamented "I have no chance to go back to school because our properties have all been destroyed and my parents are not working”. This young girl lives in the Kaningo community, she is 15 years old and she worries about her continuing school. The most vulnerable children are the female children whose parents were wounded/dead in the event of these natural disasters. Some are left without much help from siblings to take care of them, and without option they have dropped out of school. These girls are forcefully raped which result in teenage pregnancy, or some volunteer to give themselves to commercial sex. On the other hand, Jeneba Kanu, a 16 year old and SSS2 pupil also lamented that her parents were all dead in the twin disasters, and she was staying with her uncle, a charcoal seller with 8 children who cannot alone take all the responsibilities and her contemplation was to involve in commercial sex. The boy-child, on the other hand is now exploited as domestic workers engaged in petty trading, hawking pure water or other domestic work in order to earn money for the exploiters. School buildings have been affected during these disasters as some are buried in the debris of the mudslide or washed away by the flooding. These schools were the main pillars for sustaining community developments. These schools contributed to educational development which in turn increases the GDP via tax collection by the National Revenue Authority (NRA) Sierra Leone (Sierra Leone MoFED, 2017). Taking a look at their health sector, these communities were benefiting from hospitals, clinics, pharmacies etc. But that day, they were all gone due to the strike from the disasters. In other words, pharmacy and clinic were there to provide medical facilities for the people in the affected community but now majority are sick without proper medical care especially children and lactating mothers. Unless they have to travel farther to unaffected communities for medication. This greatly involves huge transportation cost. These medical centres also generate income for the owners who in turn pay tax to the Government of Sierra Leone that spurs up the GDP that could be used for national development.

\section{2) Religion}

The chart represented by Figure 10 (left) extrapolates that "Masjid/Mosque" was destroyed during the landslide and flash flood; while $13.3 \%(f=8)$ victims indicated that "Church" was destroyed when the disasters struck and 66.7 ( $\mathrm{f}=$ 40) victims stated that both "Mosque and Church" were destroyed in the process of these disasters. This has affected the religious process in those communities.

The chart reveals the evidence of the highest percentage of the destruction of Mosques and Churches during the disasters, as they contribute immensely not only to spiritual development but also social cohesion and community developments. The financial contributions (which included tithes) by individual members are often used for community development such as road construction, water 

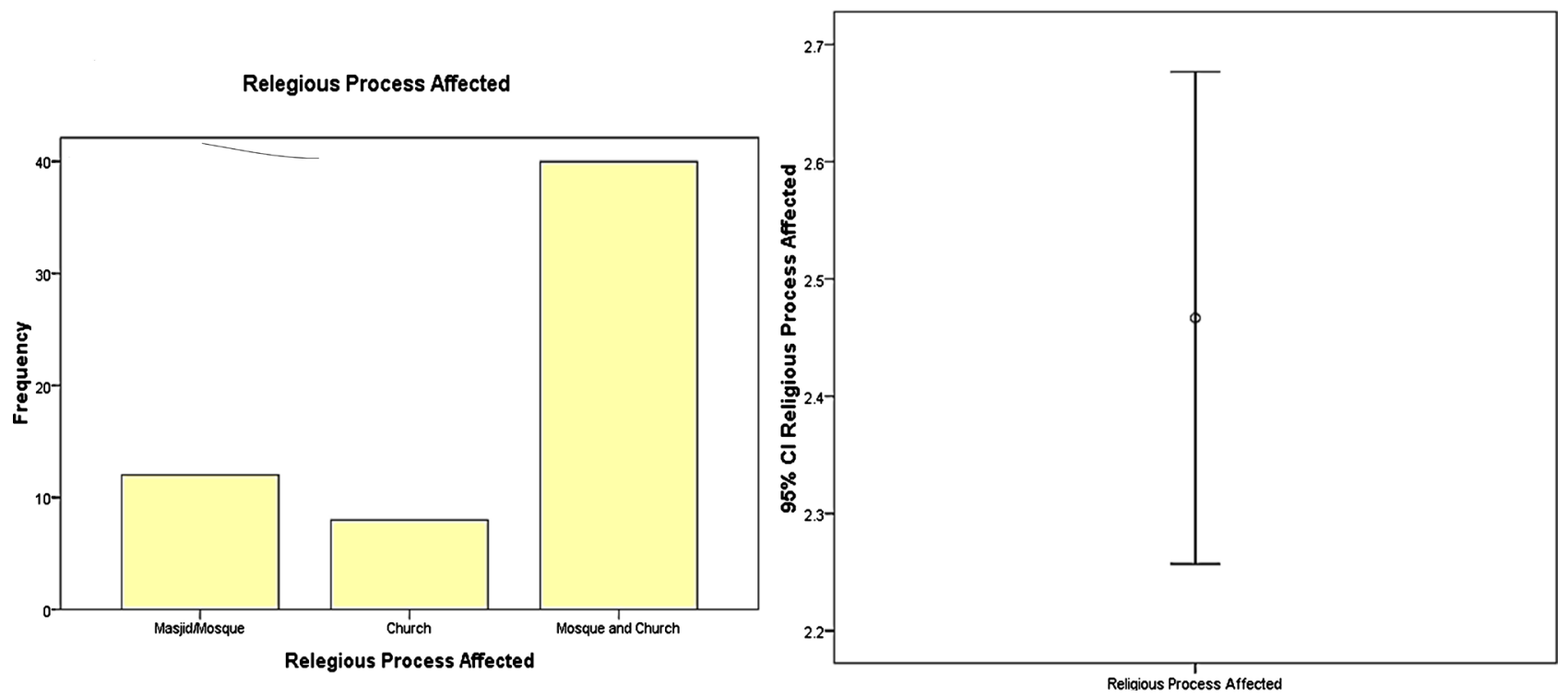

Figure 10. Effect on religion (Left) and error bar (Right) (Source: Field data on $7^{\text {th }}-9^{\text {th }} / 10 / 2017$; SPSS Version 16.0).

facility, building schools for members and non-members of the community. Shelters, food, and clothing were also provided by mosques and churches in those communities. However, most of these mosques and churches were destroyed in the wake of those disasters in that part of Freetown. This massive destruction has caused the affected communities to be without churches and mosques which were contributing positively to national development. This basically portrays the reduction in the country's GDP as they were paying royalties.

For entertainment process, it was discovered that eighty-three percent of sixty (60) victims stated that entertainment process has been seriously affected in those affected communities. Some of these entertainment activities are cultural dance, football, film-show, and other sports respectively. Community development always hinges on entertainment centres for football, and other sports. These activities bring social cohesion and also create employment within the community for sustainable development. Entertainment centres like community centre, cinema halls, cultural dance, present in these communities were affected by the dreaded disasters which destroyed them all. Football and other sporting activities are the major entertainment activities that bring people together. Not only were they bringing people together, but were contributing to the income generations for the community development. This income was used to build schools, repair bad roads, provision of pipe borne water by the strong will of councillors (Kamara, 2017b). However, the disasters stopped all the activities that were generating income for the affected communities (Mansaray, 2017). Thus, this was not good for the overall development of Sierra Leone, and will require time and money to rebuild these communities or finding new settlements. It is the responsibility of the Government of Sierra Leone, to judiciously use the Gross National Income (GNI) or donation (funds) to rebuild the affected communities, since this country is a donor driven country. 


\subsubsection{Political Effects}

Figure 11 (left) reveals, $41.7(\mathrm{f}=25)$ victims indicated "Strongly Agree" that election process would be affected in those affected communities considering the number of death of people. While $33.3(f=20)$ victims indicated "Agree" that election process are deem to be affected; $16.7(f=10)$ victims indicated "Don't Know" whether or not election process would be affected as a result of the disasters. Also, $3.3(\mathrm{f}=2)$ victims indicated "Strongly Disagree"; and $5(\mathrm{f}=3)$ victims indicated "Disagree" that the election process would be affected as a consequence of the disasters on the 14 August, 2017 in the early morning hours.

As the chart portrays that forty-one point seven percent did strongly agree that political process can also be affected when disaster strikes in any country. According to National Electoral Commission (NEC, 2017) the forthcoming election is one sure way that has been presently affected considering the number of qualified voters that have died as a result of these natural disasters. In fact those affected communities like Lumley, Regent, Matormeh and Pentagon had the most registered voters because they were densely populated. This basically will reduce the number of votes of any political party which the people in those communities represent and have opted to be ruled for the national development of the country.

However, it was also ascertained from the chart that eighty-three percent of fifty victims agreed that financial misappropriation (corruption) is also another political effect that affected them. In fact, Transparency International, 2009 ranked Sierra Leone as the $150^{\text {th }}$ of 179 countries, third highest, with corrupt practices (Economic Freedom Index, 2009). This is evident in the funds and materials donated for disaster victims and families. A physical donation estimated to the tune of more than seven million united State dollars were provided by the international community including philanthropist organisations and nations to support the mudslide victims. Some families are currently crying for not benefiting from those donations. Corruption is as rife in Sierra Leone as the ACC
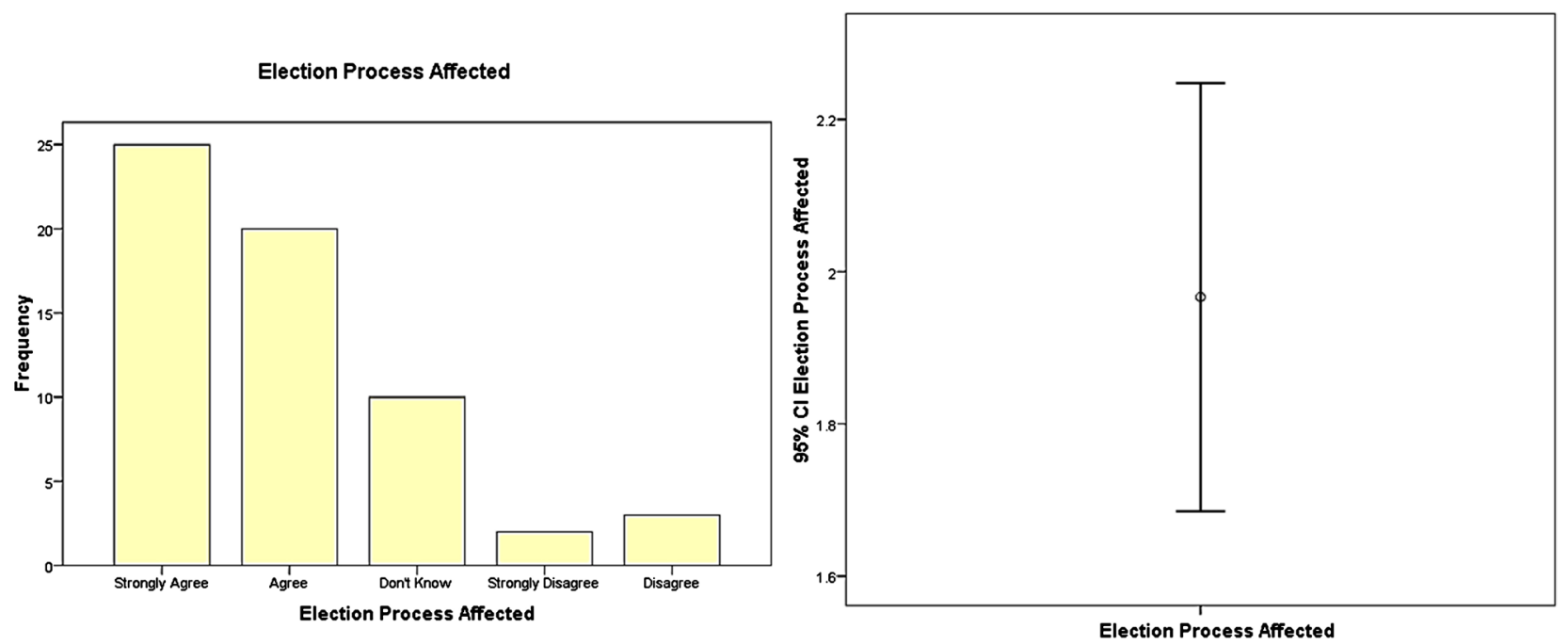

Figure 11. Impact on election process (Left) and Error bar (Right) (Source: Field data on $7^{\text {th }}-9^{\text {th }} / 10 / 2017$; SPSS Version 16.0). 
needs to be independent in their dispensation of duties especially during these natural disasters, as to punish those engage in corrupt practices depriving the deserving beneficiaries from getting the donated funds and materials as their present predicament is serious.

\subsubsection{Test of Variables and Hypothesis}

The undermentioned variables were statistically tested via the use of Student's $\mathrm{t}$-Distribution Test and Chi-square Test of certain parameters such as $\mathrm{t}_{\text {cal }}, \mathrm{t}_{\mathrm{tab}}$, $\mathrm{v}(\mathrm{df}), X_{\text {cal }}^{2}, X_{\text {tab }}^{2}$ and $\alpha$ ("alpha" at 5\% significance level) in tabular form in rejecting the null hypothesis and accepting the alternative hypothesis as the true hypothesis. The variables used are as follows: Indirect Economic Effect (IDE); Humanitarian Assistance Affected (HAA); Education and Health Affected (EHA); Religious Process Affected (RPA); Election Process Affected (EPA); Entertainment Process Affected (EnTPA); Corruption Process Affected (CA); and General Price Level Affected (GPA). Thus consider the tables:

Hypothesis: Natural disaster negatively affects Sierra Leone economically, socially and politically.

Null hypothesis $\mathrm{H}_{\mathrm{O}}: \mu=0$ OR $\mathrm{t}_{\mathrm{cal}}<\mathrm{t}_{\mathrm{tab}}$ (no significance difference between twin disasters and economic, social and political effect).

Alternative hypothesis $\mathrm{H}_{\mathrm{A}}: \mu>0$ OR $\mathrm{t}_{\text {cal }}>\mathrm{t}_{\text {tab }}$ (significance difference between twin disasters and economic, social and political effect).

Note that when $t_{\text {cal }}>t_{\text {tab }}$ (>greater than) reject $\mathrm{H}_{\mathrm{O}}$ and accept $\mathrm{H}_{\mathrm{A}}$ and $(\mu)$ is the population mean. Table 2 shows that all the variables with $t_{\text {cal }}$ are greater than $t_{\text {tab }}$ and thus we reject $\mathrm{H}_{\mathrm{O}}$ and accept $\mathrm{H}_{\mathrm{A}}$ at $5 \%$ significance difference. This means that the landslide and flash flood negatively affect Sierra Leone economically, socially and politically.

Also, for chi-square test, the decision rule is to reject $\mathrm{H}_{\mathrm{O}}$ if the computed value of $X_{\text {cal }}^{2}<X_{\text {tab }}^{2}$ while we accept $\mathrm{H}_{\mathrm{A}}$ when $X_{\text {cal }}^{2}>X_{\text {tab }}^{2}$. Assuming that $\mathrm{H}_{\mathrm{O}}: \delta$ $=0$ and $\delta>0$. Where $\delta$ is population variance and (df) is the degree of freedom. Note that the test is a two tailed test at $5 \%$ significance difference of $95 \%$ confidence interval.

Table 2. Student's t-distribution test.

\begin{tabular}{ccccc}
\hline Variable & $\mathrm{df}(\mathrm{v})(\mathrm{n}-1)$ & $\mathrm{t}_{\text {cal }}$ & $\mathrm{t}_{\text {tab }}$ & $\alpha$ (alpha) \\
\hline DEE & 59 & 12.884 & 1.645 & 0.05 \\
HAA & 59 & 20.821 & 1.645 & 0.05 \\
EHA & 59 & 17.677 & 1.645 & 0.05 \\
RPA & 59 & 23.521 & 1.645 & 0.05 \\
EPA & 59 & 13.992 & 1.645 & 0.05 \\
EnTPA & 59 & 16.954 & 1.645 & 0.05 \\
CPA & 59 & 15.470 & 1.645 & 0.05 \\
GPA & 59 & 16.116 & 1.645 & 0.05 \\
\hline
\end{tabular}

(Source: Field data; SPASS 16.0 and Probability distribution table). 
Table 3. Chi-square Test of independence.

\begin{tabular}{ccccc}
\hline Variable & $\mathrm{df}(\mathrm{v})$ & $X_{\text {cal }}^{2}$ & $X_{\text {tab }}^{2}$ & $\alpha$ (alpha) \\
\hline DEE & 7 & 85.333 & 14.067 & 0.05 \\
HAA & 5 & 20.000 & 11.070 & 0.05 \\
EHA & 2 & 35.000 & 5.991 & 0.05 \\
RPA & 2 & 30.400 & 5.991 & 0.05 \\
EPA & 4 & 34.833 & 9.488 & 0.05 \\
EnTPA & 2 & 67.600 & 5.991 & 0.05 \\
CPA & 2 & 67.600 & 5.991 & 0.05 \\
GPA & 2 & 72.100 & 5.991 & 0.05 \\
\hline
\end{tabular}

Source: Field data; SPASS 16.0 and Probability distribution table.

For chi-square test, the findings revealed that all the variables of $X_{c a l}^{2}$ are greater than $X_{\text {tab }}^{2}$ from Table 3 and thus we reject $\mathrm{H}_{\mathrm{O}}$ and accept $\mathrm{H}_{\mathrm{A}}$ to justify the alternative hypothesis stated above. In this vein it is true that whenever natural disaster occur in any country, in which Sierra Leone is no exception; this will negatively affect the economic, social and political process.

\section{Conclusion and Recommendations}

\subsection{Conclusion}

This work has presented results of geological investigations and the impacts of the disasters on economic, social, and political processes in Sierra Leone using SPSS. Therefore, the following conclusions could be drawn.

The research revealed that geological conditions played dominant role in the rainfall-triggered sugarloaf landslide underlain by fractured/jointed/bedded gabbroic rocks. Lineaments at the upper part of the slope (fault/fractures/joint sets) greatly influenced the landslide occurrence under the influence of gravity and constitute the sliding form. Relatively thick residual soil comprising numerous boulders, and cobbles indicating differential weathering, underwent rapid mass movement down slope with the presence of water (triggering factor) to form the debris slide, which eventually graded into boulder bounce. Slope destabilization at the lower gradient is strongly related to weathering, making the basal region susceptible to stream erosion and other surface processes.

For any negative effects generated from natural disasters, especially landslides and associated flash floods, there are also positive ones; including contribution to aquatic and terrestrial biodiversity, the supply of sediments/substances and woody debris to maintain pool habitat in streams and huge amount of funds donated by families, friends, organisations, international committees, countries, individuals, and religious groups in the management of disasters. However, the negative effects far outweighed the positive effects based on the magnitude of scale the most recent natural disasters struck on the $14^{\text {th }}$ August, 2017 in the very early morning hours at 6:30 AM. Study showed that hundred percent (100\%) of 
the variables tested agreed with the hypothesis that landslide and associated flash flood virtually affected the economic, social, and political process of Sierra Leone; according to the law of Student's t-Distribution Test and Chi-Square Test of Independence. Study also revealed that families assisted the most in both financial and non-financial support to the victims, and renowned misappropriation of donated disaster funds. Also, all the figures indicated small percentage at 95\% Confident Interval of uncertainty in the measurement of reported data, indicating the reliability of the measurement and confirmed that the reported value is true.

\subsection{Recommendations}

In addition to the geological context of the landslide, which dominance in the rainfall-triggered hazard on August $14^{\text {th }}$ is clear, further work on geotechnical investigation and analysis would be vital to predict the landslide occurrence and the threshold level of triggering process. This can aid in defining the threshold level of early warning and support informed policies and the development of appropriate technology for landslide hazard mitigation. Therefore, trained and qualified geologists, engineers should work in tandem with the Environment Protection Agency (EPA) and Office of the National Security (ONS) in Landslide Disaster Management (LDM) which reduces landslide risk in endangered regions and mitigate the extent of the disaster.

Education and awareness raising should be prioritized for all and sundry regarding the deadly effect of landslides and associated flash floods. In this scenario; schools, libraries of all genres should be stock with books on disaster management and protection and encourage the public to inculcate the habit of utilising libraries. There should also be community sensitization on proper housing planning and good road construction with better drainage system that could last for long.

Government of Sierra Leone-social welfare and religious group should provide psycho-social counselling for the post traumatic disorder disaster victims.

\section{Conflicts of Interest}

The authors declare no conflicts of interest regarding the publication of this paper.

\section{References}

Amnesty International (2017). Sierra Leone: Housing and Environmental Failures behinds Shocking Scale of Mudslide Death.

Bangura, M. (2017). Mudslide and Flooding in Sierra Leone.

Baraytay, A. (2017). Presidential Diary on the Effect of Mudslide and Flooding in Sierra Leone.

BBC British Broadcasting Corporation (2017). A Disaster Waiting to Happen in Freetown.

BGS British Geological Survey (2017). Sierra Leone Disaster Response. 
http://www.bgs.ac.uk

BGS British Geological Survey (2018). Landslide and Earth Observation; Power Point Presentation by David Boon.

Chalokwu, C. I. (2001). Petrology of the Freetown-Layered Complex, Sierra Leone: Part II Magma Evolution and Crystallization Conditions. Journal of African Earth Sciences, 32, 519-540. https://doi.org/10.1016/S0899-5362(01)90112-5

Dumbuya, I. (2018). Proactive Measure by Government Officials Could Have Saved Victims at Regent Mudslide (p. 17). Standard Times Newspaper, 31st May.

Economic-Freedom Index (2009). Transparency International Corruption Perception Index 2007. http://www.heritage.org/Index/country/SierraLeone

Egbejule, E. (2017). Mudslide in Sierra Leone Exposes Dangers of Freetown's Unchecked Sprawl, 2017. Freetown: Thomson Reuters Foundation.

Feizizadeh, B., \& Blaschke, T. (2011). Landslide Risk Assessment Based on GIS Multi-Criteria Evaluation: A Case Study in Bostanabad County, Iran. Journal of Earth Science and Engineering, 1, 66-71.

Free Encyclopedia (2017). The Causes and Effect of Natural Disaster.

Freetown City Council (2014). The Environmental Assessment and Evaluation of Natural Disaster Risk and Evaluation of Natural Disaster Risk and Mitigation in Freetown. Urban Planning Project 2011-14, Financed by the European Union, Freetown: Freetown City Council (FCC) and the Ministry of Lands, Country Planning and the Environment (MLCPE).

Gibbins, J. (2017). The Magnitude of Natural Disaster in Sierra Leone since 2013-2017.

Igwe, O. (2017). Report Made on Africa Landslide Disaster, 2017; A Senior Lecturer at the University of Nigeria-Landslide Expert.

Kamara, K. (2017a). Mudslide at Pentagon a New Settlement Two Miles from Mudslide.

Kamara, Y. (2017b). Flooding at Kamayama Community.

Mansaray, A. (2017). Flooding at Kaningo Community.

McAllister, E. (2017). Cities across Africa Face Threat of Landslides like Sierra Leone, 2017.

McCarthy, J. (2017). Sierra Leone Mudslides Was a Man-Made Tragedy That Could Have Been Prevented.

Ministry of Information \& Communication (2016). The Country Year Book of Sierra Leone. Freetown: Hamilton Wise Communication Ltd.

Mitchell, H. (2017). I've Seen How Perilous Life in Sierra Leone Can Be. We Cannot Ignore This Disaster. The Guardian Tabloid.

NEC National Electoral Commission (2017). The Impacts of August 14th Twin Disasters in Freetown, Sierra Leone.

Nsengiyumva, J. B., Luo, G., Nahayo, L., Huang, X., \& Cai, P. (2018). Landslide Susceptibility Assessment Using Spatial Multi-Criteria Evaluation Model in Rwanda. International Journal of Environmental Research and Public Health, 3, 23-67. https://doi.org/10.3390/ijerph15020243

Osuteye, E., \& Leck, H. (2017). Freetown's Mudslides and the Slippery Slope of Urban Risk in Africa. Sierra Leone Telegraph-Sierra Leone News.

Ramakrishnan, S. S., Sanjeevi Kumar, V., Zaffar Sadique, M. G. S. M., Arulraj, M., \& Venugopal, K. (2002). Landslide Disaster Management and Planning-A GIS Based Approach. 
Roy-Macauley, C. (2017). At Least 300 Dead in Sierra Leone Mudslide and Flooding. Freetown: Associated Press.

Salkind, N. J. (2006). Exploring Research (4th ed.). Upper Saddle River, NJ: Prentice Hall.

Sierra Leone Disaster Management Policy (2006). Final Draft on Disaster Management Policy.

Sierra Leone MoFED (2017). Disaster Management Funds.

Sierra Leone MoFED (2018). Request for Expression of Interest: Emergency Recovery Project (pp. 6-7). Global Times Newspaper, 31st May.

Sillah, S., \& Williams, B. (2017). Geological Observation of the Epicentre of the Landslide Disaster Zone. Situation Report, Freetown Landslide: Sierra Leone Institution of Scientists.

UN/OCHA United Nations Office for Coordination of Humanitarian Affairs (2017). Sierra Leone: Landslide and Floods Situation Update. UN Country Team in Sierra Leone.

UNDP \& EPA (2017). Technical Publication: Analysis of the Causal and Trigger Factors of the August 20 s17 Landslide Risk Management in Freetown, Sierra Leone. Freetown: United Nations Development Programme and Environmental Protection Agency.

UNDP (2015). Sierra Leone Millennium Development Goal. Freetown: United Nation Development Programme.

USGS U.S. Geological Survey (2015). Help Build Safer Communities, Science for a Changing World.

Westen, C. J. (2000). The Modelling of Landslide Hazards Using GIS. Surveys in Geophysics, 21, 241-255. https://doi.org/10.1023/A:1006794127521

World Bank (2017). Sugarloaf Landslide and Floods Rapid Damage and Loss Assessment in Western Sierra Leone. A Presentation. 